\title{
Synthesis of carotenoid-cysteine conjugates*
}

\author{
Afshin Zand, Attila Agócs, József Deli and Veronika Nagy ${ }^{\bowtie}$ \\ Department of Biochemistry and Medical Chemistry, Medical School, University of Pécs, Pécs, Hungary
}

\begin{abstract}
Isozeaxanthin under acidic conditions forms an allylic cation which reacts readily with thiol nucleophiles. With $\mathrm{N}$-acetylcysteine as a nucleophile the products obtained are carotenoid-cysteine conjugates in which the amino acid moiety is attached to the carotenoid via sulphur in position 4 . The water solubility of the products can be increased by deprotection of the amino group. The antioxidant activity of the products were examined on human liver cells under conditions of hydrogen-peroxide induced oxidative stress.
\end{abstract}

Key words: cysteine, isozeaxanthin, cell membrane, oxidative stress

Received: 17 October, 2011; accepted: 01 March, 2012;

available on-line: 17 March, 2012

\section{INTRODUCTION}

The natural hydrophobic carotenoids are efficient antioxidants, however, chemical synthesis of their watersoluble derivatives is reasonable to gain better bioavailability. Carotenoid nanocapsules have recently been prepared using cyclodextrins (Deli et al., 2008), as well as polyethylene glycol derivatives were covalently attached to natural carotenoid alcohols (Háda et al., 2011).

Canthaxanthin (1) is a diketocarotenoid of intense red colour widespread in nature, and is also prepared on industrial scale as a food and feed additive. Compared to other naturally occurring carotenoids canthaxanthin is relatively cheap and easily available. Here we present the synthesis of water-soluble carotenoid derivatives prepared from canthaxanthin and their effect on cells under oxidative stress.

\section{MATERIALS AND METHODS}

All reagent used for synthesis were analytically pure quality and all organic solvents were of HPLC grade. Chromatography was performed as TLC (Kieselgel 60 with fluorescent indicator $\mathrm{F}_{254}$ on aluminium sheet, Merck, with eluent hexane:acetone 2:1), or silica gel open column chromatography (Kieselgel 60, pore size 0.040-0.063 mm, Merck, with eluent hexane:acetone from $7: 1$ to $2: 1$ ).

Canthaxanthin was reduced by sodium borohydride to give isozeaxanthin with $82 \%$ yield. The product was purified by crystallisation.

A $\mathrm{CH}_{2} \mathrm{Cl}_{2}$ solution $(250 \mathrm{ml})$ of isozeaxanthin $(120 \mathrm{mg})$ was treated with trifluoroacetic acid $(4.8 \mathrm{ml})$ at $15^{\circ} \mathrm{C}$, under nitrogen athmosphere in the darkness. To the blue solution 5 equiv. of cysteine derivative were added and the mixture was strirred for $30 \mathrm{~min}$. Triethylamine was added until the solution became yellow. The mixture was washed with water $(50 \mathrm{ml}), 5 \%$ citric acid solution
$(50 \mathrm{ml})$ and brine $(50 \mathrm{ml})$. After drying over $\mathrm{MgSO}_{4}$ the solvent was evaporated under reduced pressure and the residue was purified by column chromatography or by preparative TLC. Deprotection of $N$-acetyl-cysteine derivatives was performed in dry methanol by sodium methylate.

The reaction mixtures were analysed by TLC and HPLC, the prepared compunds were identified by NMR, UV-VIS spectroscopy, and mass spectrometry (MALDITOF).

The protective effect of the $N$-acetylcysteine derivatives were studied on WRL-68 type human liver cells in hydrogen-peroxide induced oxidative stress (Tapodi et al., 2005). The isomers ( $4 S$ and $4 R$ ) were applied together in a mixture. As a reference the effect of isozeaxanthin of poor water solubility was also examined. For the treatment of the cells the carotenoids were applied in three different types of solutions of $10 \mu \mathrm{M}$ carotenoid concentration: (A) the prepared $N$-acetylcysteine derivatives were dissolved in aqueous Eagle's medium. (B) Since the reference isozeaxanthin is insoluble in water, it was first dissolved in DMSO in $1 \mathrm{mM}$ concentration, which was diluted by aqueous Eagle's medium to the final concentration. DMSO containing solution of the $N$-acetylcysteine derivatives was prepared the same way. (C) To facilitate the carotenoid absorption by the cells both carotenoids were treated with lecithin to form liposomes (Socaciu et al., 1999), which were applied in the Eagle's medium aqueous solutions in a $10 \mu \mathrm{M}$ of final carotenoid concentration (determined by UV-VIS spectroscopy).

Each of these solutions were applied in 6-6 parallel measurements, the cells were incubated with the carotenoids during 3 hours before $\mathrm{H}_{2} \mathrm{O}_{2}$ treatment. Oxidative stress was induced by treatment with $\mathrm{H}_{2} \mathrm{O}_{2}$ in $300 \mu \mathrm{M}$ concentration for 3 hours. The results were compared with analogous measurements for untreated cells. The effect of carotenoid liposomes was compared to the cells treated by equal amount of lecithin.

\section{RESULTS AND DISCUSSION}

The $\mathrm{NaBH}_{4}$ reduction of canthaxanthin (1) gave isozeaxanthin (4,4'-dihydroxy- $\beta, \beta$-carotene, 2$)$ containing allylic hydroxy groups. Previously, this non-natural carotenoid served as a precursor of carotenoid glycosides synthetized by a new method (Nagy et al., 2010):

On trifluoroacetic acid treatment isozeaxanthin gave a blue coloured cation of a charge +2 , which reacted readily with nucleophiles in positions 4 and 4' (Lutneas et al.,

e-mail: vera.nagy@aok.pte.hu

*Presented at the 16th International Symposium on Carotenoids, 17-22 July, 2011, Kraków, Poland 


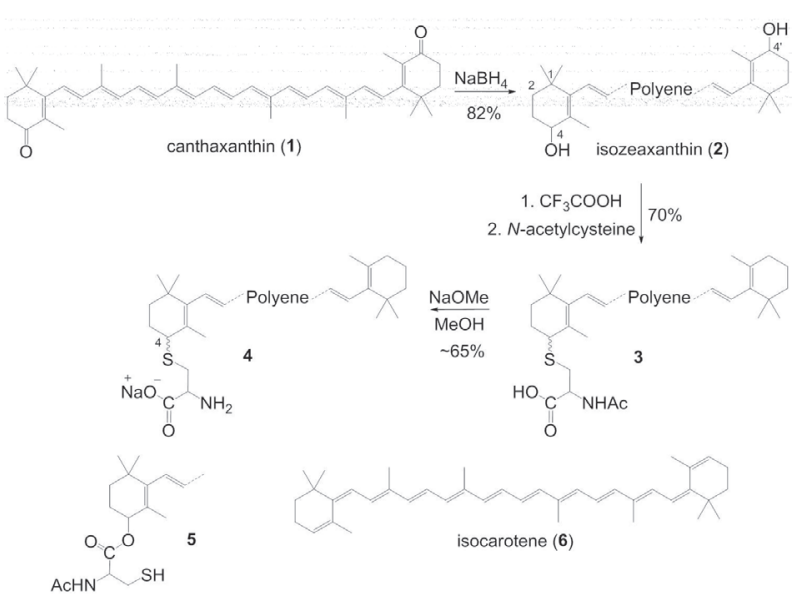

Figure 1. Synthesis of (4RS)-4((2R)-2-carboxy-2-amino-ethylthio)$\beta, \beta$-carotene from canthaxathin.

2004). Using tetra-O-benzoyl-1-thio- $\beta$-D-glucopyranose as nucleophile thioglycosides were obtained in good yields.

Reaction of the similarly prepared cation with Lcysteine was also examined. The free amino group of cysteine behaved as a base and deprotonated the cation, as expected. Under these conditions no substitution product was observed, only the formation of isocarotene (6) was detected (Fig. 1).

Using $N$-acetyl-L-cysteine the expected reaction occurred and conjugates 3 were isolated in good yields. The carboxyl group of $N$-acetyl-L-cysteine can also behave as a nucleophile, however, the formation of ester $\mathbf{5}$ was not observed.

The acetyl protective group was removed in methanol by excess of sodium methylate, which produced the water-soluble sodium salts of the cysteine conjugates (4).

Spectroscopic data for (4RS)-4((2R)-2-carboxy-2acetamido-ethylthio)- $\beta, \beta$-carotene (3): $\lambda_{\max }: 451,475 \mathrm{~nm}$ (in ethanol). ${ }^{1} \mathrm{H}-\mathrm{NMR}\left(\mathrm{CDCl}_{3}, 400 \mathrm{MHz}\right): \delta$ (ppm) 6.32$6.55(\mathrm{~m}, 8 \mathrm{H}$, polyene chain), 6.33-6.00 ( $\mathrm{m}, 20 \mathrm{H}$, polyene

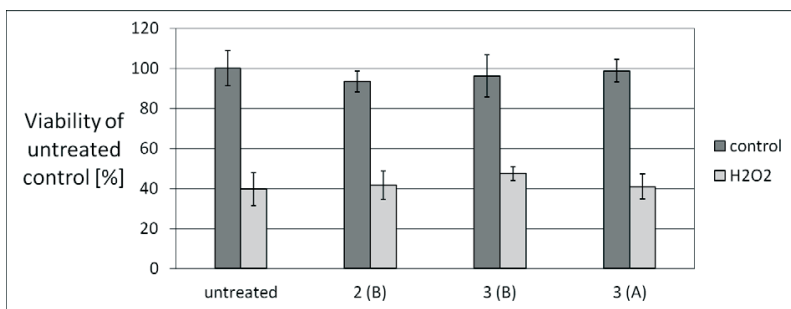

Figure 2. Effect of 3 and isozeaxanthin (2) in $\mathrm{H}_{2} \mathrm{O}_{2}$ induced oxidative stress.

(A) Aqueous solution of 3. (B) The carotenoid was first dissolved in small a amount of DMSO and was diluted by aqueous solution.

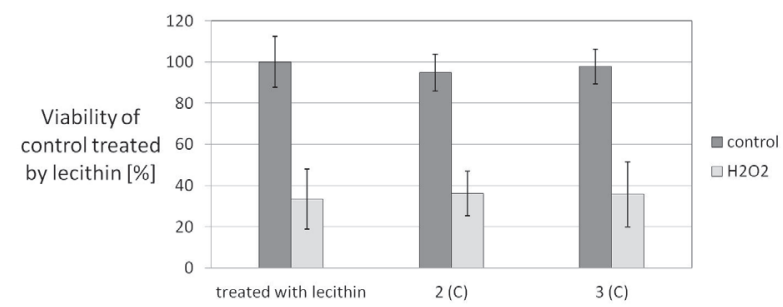

Figure 3. Effect of liposomes with 3 or isozeaxanthin (2) in $\mathrm{H}_{2} \mathrm{O}_{2}$ induced oxidative stress.

(C) Aqueous solution of liposomes with carotenoids. chain), 4.70 ( $\mathrm{m}, 2 \mathrm{H}, \alpha \mathrm{CH}$ of cysteine), 3.24 and 3.18 (2ps, $4 \mathrm{H}, \beta \mathrm{CH}$ s of cysteine), 3.12 and 3.09 (2d, $J=7.0$ $\mathrm{Hz}, 2 \mathrm{H}, \mathrm{H}-4$ of $4 \mathrm{~S}$ and $4 \mathrm{R}$ compounds), 2.01, 1.92, $1.90,1.81$ (s, 24H, methyl $H$ at C-19, C-20, and C-19', C-20') $1.38,1.25,1.19,1.03,1.00,(\mathrm{~s}, 36 \mathrm{H}$, methyl $H$ at C-16, C-17, C-18, and C-18', C-17' C-16'). ${ }^{13} \mathrm{C}-\mathrm{NMR}$ $\left(\mathrm{CDCl}_{3}, 100 \mathrm{MHz}\right): \delta$ (ppm) 171.80, 170.10 and 169.94 (s, 4C, COOH and CONH), 142.30, 138.54, 137.53, $136.29,135.35,132.49,131.46,129.92,127.18,125.72$, 124.71, 117.99 (s, 44C, polyene chain and C5, C-6, C-6', C-5'), 52.42 and 52.28 (s, 2C, $\alpha \mathrm{CH}$ of cysteine), 49.87 and 49.75, (s, 2C, C4), 34.46, 34.36, 33.94, 33.73, 29.68, $27.59,25.85,25.76,22.99,20.69,12.63,12.58,12.53$ (s, 34C, C1, C-2, C-3, C-16-C20, and C1' C-2', C-3', C-4', C-16'-C-20'. MS: $697.2 \quad[\mathrm{M}]^{+} \quad \mathrm{C}_{45} \mathrm{H}_{63} \mathrm{NO}_{3} \mathrm{~S}$ (MALDITOF).

Preliminary assays on the protective effects of the prepared carotenoids were executed on liver cells in hydrogenperoxide induced oxidative stress. We did not examine if the carotenoids enter the cells or they have an external effect.

The prepared carotenoids both in aqueous solutions and in liposomes showed a little protective effect. Cell survival after $\mathrm{H}_{2} \mathrm{O}_{2}$ treatment was increased by $6-7 \%$ compared to cells not treated with carotenoids (Fig. 2, Fig. 3).

No difference was found between the protective effect of carotenoids in aqueous solutions and that of the liposomes. The viability of the cells after the $\mathrm{H}_{2} \mathrm{O}_{2}$ treatment was found to be lower with liposomes; the same effect was seen in the case of the reference treated only by lecithin. This suggest that the presence of lecithin made the cells more susceptible to hydrogen peroxide treatment.

However, the obtained data show that the carotenoid conjugates obtained are not toxic, the cells treated by them even in a $30 \mu \mathrm{M}$ concentration showed 96-98\% viability.

\section{Acknowledgements}

We are grateful to DSM Nutrition Products for their generous supply of canthaxanthin. We thank Mrs. Izabella Solti for her help in the biological assays, Mrs. Erika Radó-Turcsi for the HPLC measurements, Dr. Anikó Takátsy for the MS measurements, Mr. Gergely GulyásFekete for the NMR measurements.

This research was founded by the National Research Fund (OTKA K 83898, PD 77467).

\section{REFERENCES}

Deli J, Agócs A, Iványi R, Németh K, Visy J, Szemán J, Szente L, Simonyi M (2008) Preparation and characterization of water soluble carotenoid/cyclodextrin complexes. Carotenoid Sci 12: 201.

Háda M, Petrovics D, Nagy V, Böddi K, Deli J, Agócs A (2011) The first synthesis of PEG-carotenoid conjugates. Tetrabedron Lett 52: 3195-3197.

Lutneas BJ, Kildahl-Andersen G, Krane J, Liaaen-Jensen S (2004) Delocalized carotenoid cations in relation to the soliton model. $\mathrm{J} \mathrm{Am}$ Chem Soc 126: 8981-8990.

Nagy V, Agócs A, Turcsi E, Deli J (2010) Experiments on the synthesis of carotenoid glycosides. Tetrahedron Lett 51: 2020-2022.

Socaciu C, Lausch C, Diehl HA (1999) Carotenoids in DPPC vesicles: membrane dynamics. Spectrochim Acta Part A 55: 2289-2297.

Tapodi A, Debreceni B, Hantó K, Bognár Z, Wittmann I, Gallyas F, Várbíró G, Sümegi B (2005) Pivotal role of Akt activation in mitochondrial protection and cell survival by poly(ADP-ribose) polymerase-1 inhibition in oxidative stress. If Biol Chem 280: 35767-35775. 